DOI https://doi.org/10.30525/978-9934-571-83-1-31

\title{
ПРОТИДІЯ НЕНАСИЛЬНИЦЬКИМ СТАТЕВИМ ЗЛОЧИНАМ ПРОТИ НЕПОВНОЛІТНІХ В УКРАЇНІ ТА ІНШИХ ДЕРЖАВАХ
}

\author{
Хряпінський П. В., Світличний О. О.
}

\section{ВСТУП}

Порівняльно-правове дослідження відповідальності за ненасильницькі статеві злочини з особами, які не досягли певного віку, у кримінальному праві України та країнах СНД та СС надає багато прикладів щодо підвищення ефективності протидії цим злочинам. Європейські кримінально-правові системи стикаються 3 низкою труднощів, які пов'язані з істотними розбіжностями в історичних і культурних уявленнях національних спільнот, що складалися сторіччями. Кримінальна відповідальність за злочини проти статевої недоторканості містить велику кількість суттєвих юридичних особливостей, уніфікація яких потребує додаткових досліджень. Для розгляду нами було обрано кримінальне законодавство України та дружніх сусідніх країн (Білорусі, Молдови, Грузії, Казахстану, Азербайджану, Вірменії та Узбекистану), а також країн Європейського Союзу - Польщі, Болгарії, Австрії, прибалтійських країн, Федеративної Республіки Німеччини (далі - ФРН) та Іспанії.

3 набуттям чинності Закону України від 14.03 .2018 р. № 2334-VIII «Про внесення змін до Кримінального кодексу України щодо захисту дітей від сексуальних зловживань та сексуальної експлуатації» ${ }^{1}$ протидія ненасильницьким статевим злочинам проти дітей набула особливої гостроти та актуальності. $€$ підстави визначення нового етапу протидія статевим злочинам проти неповнолітніх. У новій редакції викладені, відповідно, ст.ст. 155 та 156 Кримінального кодексу України 2001 р. (далі КК). Так, ст. 155 «Статеві зносини 3 особою, яка не досягла шістнадцятирічного віку» набула такого вигляду: «1. Природні або неприродні статеві зносини з особою, яка не досягла шістнадцятирічного віку, вчинені повнолітньою особою, караються обмеженням волі на строк до п'яти років або позбавленням волі на той самий строк. 2. Ті самі дії, вчинені близькими родичами або членами сім'ї, особою, на яку покладено обов'язки щодо виховання потерпілого або піклування про нього, або якщо

\footnotetext{
1 Про внесення змін до Кримінального кодексу України щодо захисту дітей від сексуальних зловживань та сексуальної експлуатації : Закон України від 14.03.2018 р. Відомості Верховної Ради (BВP). 2018. № 17. С т. 150.
} 
вони спричинили безплідність чи інші тяжкі наслідки, караються позбавленням волі на строк від п'яти до восьми років із позбавленням права обіймати певні посади чи займатися певною діяльністю на строк до трьох років або без такого. Примітка. У ст.ст. 155, 156 цього Кодексу під близькими родичами або членами сім'ї треба розуміти осіб, визначених пунктом 1 частини першої ст. 3 Кримінального процесуального кодексу України». Розбещення неповнолітніх в ст. 156 КК викладене як: «1. Вчинення розпусних дій щодо особи, яка не досягла шістнадцятирічного віку, карається обмеженням волі на строк до п'яти років або позбавленням волі на той самий строк. 2. Ті самі дії, вчинені щодо малолітньої особи або вчинені членами сім'ї чи близькими родичами, особою, на яку покладено обов'язки щодо виховання потерпілого або піклування про нього, караються позбавленням волі на строк від п'яти до восьми років із позбавленням права обіймати певні посади чи займатися певною діяльністю на строк до трьох років або без такого».

\section{1. Протидія статевим зносинам та іншим діям сексуального характеру з особою, яка не досягла певного віку}

У КК Республіки Білорусь статеві злочини передбачені у Главі 20 «Злочини проти статевої недоторканості або статевої свободи» 2 . Кримінальна відповідальність за статеві зносини та інші дії сексуального характеру з особою, яка не досягла шістнадцятирічного віку, передбачена у ст. 168 КК РБ. Ця кримінально-правова норма має таку диспозицію: статеві зносини, мужолозтво, лесбіянство чи інші дії сексуального характеру, вчинені особою, яка досягла вісімнадцятирічного віку, з особою, яка завідомо не досягла шістнадцятирічного віку, за відсутності ознак злочинів, передбачених ст.ст. 166, 167 цього Кодексу, карається обмеженням волі на строк до чотирьох років або позбавленням свободи на той самий строк зі штрафом. У частині другій передбачено вчинення тих самих дій, особою, що раніше вчинила злочини, передбачені цією статтею, ст.ст. 166, 167 цього Кодексу, або особою, на яку покладені обов'язки 3 виховання, утримання, забезпечення безпеки життя i здоров'я неповнолітнього, або групою осіб, карається позбавленням свободи на строк від трьох до десяти років. Варто зазначити, що в практиці застосування кримінально-правових норм, передбачених ст.ст. 168, 169 КК РБ, є проблема розмежування однорідних суспільно небезпечних діянь. Неважко передбачити певне «конкурування» понять «інші дії сексуального характеру» (ст. 168) і «розпусні дії» (ст. 169 КК), що майже збігаються.

\footnotetext{
${ }^{2}$ Уголовный кодекс Республики Беларусь от 17.07.2018 г. Официальный сайт Верховного Совета Республики Беларусь. URL: http://www.sovrep.gov.by/ru/
} 
КК Республіки Молдова ${ }^{3}$ в ст. 174 встановив відповідальність за статеві зносини 3 особою, яка не досягла 16 років. Ця стаття містить такий основний склад злочину: статеве зношення, інший вид згвалтування, акти вагінального, анального, орального або іншого проникнення, вчинення щодо особи, яке завідомо не досягла 16 років, караються позбавленням свободи на строк від 3 до 7 років. Частина друга цієї статті має норму такого змісту: «Особа, яка вчинила діяння, передбачене частиною 1 цієї статті, не підлягає кримінальній відповідальності, якщо вона близька за віком, фізичному і психічному розвитку до потерпілого (потерпілої)»

Ст. 140 КК Грузіі ${ }^{4}$ встановлює відповідальність за статеві зносини, мужолозтво, лесбіянство чи інші сексуальні контакти повнолітнього в неприродній формі з особою, яка завідомо для винуватого не досягла шістнадцятирічного віку, та карає ці дії позбавленням свободи на строк від семи до десяти років. Ст. 141 «Розпусні дії» передбачає, що розпусні діяння без застосування насильства щодо особи, яка завідомо для винуватого не досягла шістнадцятирічного віку, караються позбавленням свободи на строк від п'яти до семи років. Як бачимо, КК Грузії уніфікував вік потерпілих від цих злочинів, тим самим усунув колізію, що $є$ в багатьох законах країн СНД.

Відповідальність за статеве зношення або інші дії сексуального характеру щодо особи, яка не досягла шістнадцятирічного віку, встановлена в ч. 1 ст. 122 КК Республіки Казахстан 5 та містить таку диспозицію: статеве зношення, мужолозтво чи лесбіянство з особою, яка завідомо не досягла шістнадцятирічного віку, караються обмеженням волі до п’яти років або позбавленням свободи на той самий строк. Суттєвим недоліком цього КК варто вважати відсутність самостійного розділу про злочини проти статевої свободи і статевої недоторканості. Відповідні склади злочинів містить глава I «Злочини проти особи» (ст.ст. 120-124 КК). Казахський законодавець останнім часом посилив кримінальну відповідальність за вчинення цього діяння в ч.ч. 2 та 3 ст. 122 КК, передбачивши кваліфікуючими ознаками вчинення тих самих дій щодо особи, що не досягла шістнадцятирічного віку, батьками, педагогом або іншими особами, на яких законом Республіки Казахстан покладені обов'язки з ії виховання (ч. 2), та вчинення діяння, передбачене ч.ч. 1, 2 цієї статті, вчинене неодноразово (ч. 3). Зазначимо й ту особливість, що як

\footnotetext{
${ }^{3}$ Уголовный кодекс республики Молдова от 18.04.2002 г. Официальный сайт Верховного Совета Республики Молдова. URL: http://lex.justice.md/ru/331268/.

4 Уголовный кодекс Грузии от 22.07.1999 г. Законодательный вестник Грузии. URL: https://matsne.gov.ge/ru/document/view/16426?publication=205.

5 Уголовный кодекс Республики Казахстан от 03.07.2014 г. URL: https://online.zakon.kz/ Document/?doc_id=31575252\#pos=5;-245.
} 
санкцію в ч. 3 ст. 122 КК передбачено позбавлення свободи на строк від десяти до п'ятнадцяти років із пожиттєвим позбавленням права обіймати певні посади або займатися певною діяльністю.

Зазначимо, що КК Латвійської Республіки ${ }^{6}$ передбачає відповідальність за статеві злочини в главі XVI Особливої частини «Злочинні діяння проти моральності і статевої недоторканості». Ст. 161 КК встановлює відповідальність за статеве зношення, педерастію та лесбіянство або інше задоволення статевої пристрасті неприродним шляхом 3 особою, яка не досягла шістнадцятирічного віку і перебувала у матеріальній чи іншій залежності від винного, або вчинення цього діяння повнолітньою особою. За це діяння передбачене покарання у вигляді позбавлення свободи на строк до чотирьох років.

Особливістю Кримінального Закону Литовської Республіки ${ }^{7} \epsilon$ відсутність самостійної статті, що передбачала б кримінальну відповідальність за статеві зносини 3 малолітньою особою. Глава XXI Особливої частини КЗ має назву «Злочини і кримінальні проступки проти свободи сексуального самовизначення і сексуальної недоторканості людини». Ближчою до юридичної сутності зазначеної поведінки є ст. 153 КК: «Розпусні дії щодо малолітньої особи караються штрафом або обмеженням свободи, або арештом, або позбавленням свободи на строк до двох років». Ймовірно, саме цією кримінально-правовою нормою охоплюються будь-які добровільні статеві зносини з малолітньою особою. Якщо ж потерпіла особа досягла 14-річного віку, то добровільні статеві зносини з нею не $є$ кримінально караними.

Пенітенціарний кодекс Естонії, який, по суті, є кримінальним, а не кримінально-виконавчим кодексом, як може здатися 3 назви, містить самостійний Розділ 7 «Винні діяння проти сексуального самовизначення» (ст.ст. 141-147). Кримінальна відповідальність за статеві зносини 3 особою, яка не досягла певного віку, міститься в ч. 1 ст. 145 «Статеве зношення або інші дії сексуального характеру з малолітнім», передбачає відповідальність за вступ повнолітнього особи в статеве зношення або інші дії сексуального характеру з особою, яка не досягла чотирнадцятирічного віку, караються тюремним ув'язненням на строк до п'яти років. У ч. 2 цієї статті передбачено вчинення тих самих дій особою, що раніше вчинила злочин, який передбачений цим розділом та карається тюремним ув'язненням на строк від двох до восьми років. У третій частині

\footnotetext{
6 Уголовный кодекс Латвийской Республики 17.06.1998 г. Сейм Латвийской Республики. URL: http://www.pravo.lv/likumi/07_uz.html.

7 Уголовный закон Литовской Республики 26.07.2000 г. URL: http://www.law.edu.ru/norm/norm.asp? normID=1243877\&subID=100107735,100107738,100107759,100107839\#text.
} 
передбачається відповідальність за такі діяння юридичної особи ${ }^{8}$. За вчинення злочину, вказаного в цій статті, суд може застосувати до юридичної особи розширену конфіскацію майна, здобутого в результаті вчинення цього злочину, згідно положенням ст. 832 Кодексу Естонії. Особливістю кримінального законодавства Естонії є наявність спеціальної відповідальності за статеве зношення або інші дії сексуального характеру, вчинені батьками, особами, що володіють батьківськими правами, дідусями та бабками щодо дочок, синів, онуків (ст. 144 ПК). При цьому законодавець не позначає вік потерпілої особи. В ст. 145-1 передбачається відповідальність за купівлю сексуальних послуг у неповнолітнього.

У ст. 152 КК Азербайджанської Республіки ${ }^{9}$ встановлено кримінальну відповідальність за вступ у статевий зв'язок або вчинення інших дії сексуального характеру з особою, яка не досягла шістнадцятирічного віку. Карається цей злочин позбавленням свободи на строк до трьох років. Ті самі дії, вчинені щодо особи, яка не досягла чотирнадцятирічного віку, караються позбавленням свободи на строк від трьох до шести років. Діяння, зазначені в ст. 152.1 або ст. 152.2 цього Кодексу, вчинені особами, на яких покладено обов'язок із виховання неповнолітніх, або вчителем або іншим працівником освітнього, виховного, медичного або іншого закладу, на якого покладено обов'язок щодо здійснення нагляду над повнолітніми, караються позбавленням волі на строк від чотирьох до семи років із позбавленням права обіймати певні посади чи займатися певною діяльністю на строк до трьох років або без такого. Згідно з приміткою до ст. 152 КК АР відповідальність за злочини, передбачені ст.ст. 152, 153 цього Кодексу, виникає, якщо різниця між віком особи, яка вчинила зазначені в цих статтях діяння, і віком потерпілого - понад два роки.

КК Республіки Вірменія ${ }^{10}$ відповідальність за цей злочин встановлено в ст. 141 «Вчинення дій сексуального характеру 3 особою, яка не досягла шістнадцяти років», в якій передбачено відповідальність за статеве зношення особи, яка досягла вісімнадцятирічного віку, або вчинення інших дій сексуального характеру 3 особою, завідомо не досягла шістнадцятирічного віку, за відсутності ознак злочинів, передбачених ст.ст. 138, 139 або 140 цього Кодексу, караються виправними роботами на строк не більше двох років або позбавленням волі на строк не більше двох років. У цьому КК чіткіше окреслено добровільний характер статевих

\footnotetext{
${ }^{8}$ Пенитенциарный кодекс Эстонии 06.06.2001 г. URL: https://v1.juristaitab.ee/sites/www.juristaitab.ee/ files/elfinder/ru-seadused/

9 Уголовный кодекс Азербайджанской Республики от 30.12.1999 г. URL: http://law.edu.ru/norm/ norm.asp?normID=1242908\&subID=100104131,100104133,100104144,100104987,100105115.

10 Уголовный кодекс Республики Армения от 29.04.2003 p. URL: http://www.parliament.am/ legislation.php?sel=show \&ID=1349\&lang=rus\#18.
} 
зносин чи інших дій сексуального характеру, але також не проводиться розмежування понять «інші дії сексуального характеру» і «розпусні дії», відповідальність за які передбачена ст. 142 КК.

У Розділі 4 «Злочини проти статевої свободи» КК Республіки Узбекистан ${ }^{11}$ міститься чотири склади злочинів: ст. 118 «Згвалтування», ст. 119 «Насильницьке задоволення статевої потреби у неприродній формі», ст. 120 «Мужолозтво» (бесакалбазлик), ст. 121 «Примушування жінки до вступу у статевий зв'язок». Особливістю цього КК $є$ те, що відповідальність за вступ у статевий зв'язок 3 особою, яка не досягла 16 років (ст. 128 КК), і за розпусні дії щодо особи, яка не досягла 16 років (ст. 129 КК), передбачена у Розділі 5 «Злочини проти сім’ї, молоді і моральності». В ст. 128 КК «Вступ у статевий зв'язок з особою, яка не досягла шістнадцяти років» статеві зносини або задоволення статевої потреби в протиприродній спосіб з особою, яка завідомо для винного не досягла шістнадцяти років, караються обов'язковими громадськими роботами до трьохсот шістдесяти годин або виправними роботами до двох років або обмеженням волі від одного року до трьох років або позбавленням волі до трьох років. Ті самі дії, вчинені: а) повторно або небезпечним рецидивістом; б) особою, яка раніше вчинила злочини, передбачені ст. 118 або ст. 119 цього Кодексу, - караються обмеженням волі від трьох до п'яти років або позбавленням волі від трьох до п'яти років.

У КК Республіки Польща ${ }^{12}$ група статевих злочинів об'єднується найменуванням «Злочини проти сексуальної свободи і моральності». Ці суспільно небезпечні діяння зосереджені у ст.ст. 197-205 глави 25 Особливої частини КК. Кримінальна відповідальність за ненасильницькі статеві зносини 3 малолітньою особою, яка не досягла 15 років, встановлена в ст. 200 КК РП. В §1 цієї статті передбачається, що той, хто доводить малолітнього віком молодше за 15 років до статевих зносин чи стану, коли він підкоряється здійсненню щодо нього сексуальних дій або коли він вчиняє такі дії, підлягає покаранню позбавленням свободи на строк від одного року до десяти років. У §2 вказаної статті вказується, що такому самому покаранню підлягає той, хто фіксує порнографічний зміст за участю такої особи. В Польщі відповідальність за статеві зносини 3 особою, яка не досягла статевої зрілості, не диференціюється за допомогою кваліфікуючих ознак. Водночас у ст. 201 передбачається спеціальний склад статевого злочину, який становить добровільні статеві

\footnotetext{
${ }^{11}$ Уголовный кодекс Республики Узбекистан від 24.09.1994 г. Законы Республики Узбекистан. URL: http://lex.uz/docs/111457\#158462.

12 Уголовный кодекс Республики Польша от $01.03 .2007 \quad$ г. URL: http://law.edu.ru/norm/ norm.asp?normID=1246817\&subID=100110056,100110058,100110087,100110285\#text
} 
зносини 3 родичем по висхідній і спадній лінії, усиновленим, усиновителем, братом чи сестрою. Така особа підлягає покаранню позбавленням волі на строк від трьох місяців до п’яти років. Автори вступної статті до КК РП не зовсім точно, на наш погляд, зазначили, що ст. 201 КК Польщі передбачає спеціальну відповідальність за інцест ${ }^{13}$. Поперше, статті КК РП не мають назв та в ст. 201 термін «інцест» взагалі не вживається. По-друге, під інцестом у сексології розуміються кровозмішні зв'язки між родичами, а суб'єктом такого злочину може бути не тільки родич по висхідній чи спадній лінії, брат чи сестра, а й усиновитель (чи усиновлена особа). 3 огляду на особливості суб'єктного складу цього злочину можна зазначити, що ст. 201 КК РП передбачає кримінальну відповідальність за статеві зносини будь-якого характеру (інцестного й неінцестного).

Статеві злочини в КК Болгарії 1968 p. ${ }^{14}$ містяться у восьмому розділі глави II Особливої частини «Злочини проти особи». Розділ 8 має назву «Розпуста» і містить 11 статей (ст.ст. 149-159 КК). У ст. 151 КК передбачається три частини. В частині першій встановлено відповідальність особи, в якої $є$ статеві зносини 3 особою, якій не виповнилося 14 років, оскільки акт не становить злочин відповідно до ст. 152, має бути покараний позбавленням свободи протягом від двох до шести років. Коли ж злочинне діяння, що підпадає ч. 1 цієї статті, є незначним або вчинено приватною особою, то карається штрафом або обмеженням свободи строком від одного до п'яти років (ч. 2 ст. $151 \mathrm{KК}$ РБ). У ч. 3 цієї статті передбачається відповідальність особи, в якої є статеві зносини з особою, якій вже виповнилося 14 років, хто розуміє сутність і значення акту, має бути покараний позбавленням свободи протягом п’яти років. Особливістю $є$ наявність окремої заохочувальної норми, що містить положення про некараність діяння винуватої особи 3 урахуванням ऑii позитивної посткримінальної поведінки. Ст. 158 КК Болгарії зазначає, що у випадках, зазначених у ст.ст. 149-151, 153 КК, особа не підлягає покаранню або призначене покарання не виконується, якщо до приведення вироку у виконання між чоловіком і жінкою був укладений шлюб ${ }^{15}$.

КК Австрії не містить окремого розділу про відповідальність за статеві злочини, a включає їх $\mathrm{y}$ десятий розділ «Злочинні діяння проти

\footnotetext{
${ }^{13}$ Уголовный кодекс Республики Польша / Науч. ред. А.И. Лукашов, Н.Ф. Кузнецова. Вступ. статья А.И. Лукашов, Э.А. Саркисова. Санкт-Петербург : Юридический центр Пресс, 2001. С. 38.

14 Уголовный кодекс Болгарии. Опубликовано 27.11.2011 г. URL: http://ugolovnykodeks.ru/2011/11/ ugolovnyj-kodeks-bolgarii/

15 Хавронюк М.І. Кримінальне законодавство України та інших держав континентальної Європи: порівняльний аналіз, проблеми гармонізації : монографія. Київ : Юрисконсульт, 2006. С. 691.
} 
моральності», поряд з іншими злочинами проти моральності. Нормами, що передбачають кримінальну відповідальність за ненасильницькі статеві зносини з малолітніми особами (за винятком розпусних дій), згідно з КК Австрії є: 1) тяжкі сексуальні дії щодо малолітніх (§ 206); 2) гомосексуальні дії щодо осіб, які не досягли 18-річного віку (§ 209 КК); $3)$ зловживання батьківськими й іншими правами (§ 212 КК $)^{16}$. Серед перелічених статей провідне місце посідає § 206 КК Австрії «Тяжкі сексуальні дії щодо малолітніх». Абзац 1 цього параграфа передбачає, що той, хто здійснює статеве співжиття 3 малолітнім чи вчиняє щодо нього іншу, рівносильну статевому співжиттю сексуальну дію, карається позбавленням волі на строк від одного до десяти років. При цьому під «малолітньою особою» КК Австрії розуміє особу, яка не досягла 14річного віку. Абзац 2 цього параграфа передбачає припис про відповідальність за схиляння малолітнього до вчинення чи допущення статевого співжиття чи іншої, рівносильної статевому співжиттю сексуальної дії з іншою особою, чи для того, щоб сексуально збудитися або задовольнитися самому, або збудити чи задовольнити третю особу. Санкція аналогічна тій, що передбачена в першому абзаці. Варто звернути увагу, що відповідальність за особливий випадок схиляння малолітньої особи до сексуальних дій передбачений абз. 1 § 212: «Зловживання батьківськими й іншими правами, що хто схиляє до статевого співжиття свою дитину, прийомну дитину, пасинка (пасербицю) чи підопічного і хто вчиняє ці дії, використовуючи своє особливе становище в зв'язку з іiі вихованням, освітою чи наглядом за малолітньою особою, чи для того, щоб сексуально збудитися чи задовольнитися самому або сексуально збудити чи задовольнити третю особу, схиляє зазначену вище особу до вчинення сексуальної дії щодо себе самого, той карається позбавленням волі на строк до трьох років». Абз. $3 \S 206$ передбачає кваліфікуючі обставини: «Якщо діяння спричинило заподіяння тяжкого тілесного ушкодження чи настання вагітності в малолітньої особи, то покаранням $\epsilon$ позбавлення волі на строк від п'яти до п’ятнадцяти років, а якщо діяння потягло за собою смерть малолітньої особи, то покаранням є позбавлення волі на строк від десяти до двадцяти років». Своєрідною в КК Австрії $€$ норма, яка передбачає спеціальний вид звільнення від кримінального переслідування за ненасильницькі статеві контакти з малолітньою особою. Якщо особа старша за потерпілого не більше аніж на три роки, сексуальна дія не супроводжувалася введенням предмета і діяння не потягло за собою ні тяжкого тілесного ушкодження, ні смерті малолітньої особи, то особа,

\footnotetext{
16 Уголовный кодекс Австрии. Москва : Юридическая литература, 2004. 352 c. URL: https://www.livelib.ru/book/1001353291/about-ugolovnyj-kodeks-avstrii/.
} 
яка вчинила діяння, не карається відповідно до абз. 1 і 2, за винятком тих випадків, коли малолітня особа ще не досягла 13-річного віку (абз. 4 § 206 КК Австріi).

У КК Іспанії 1995 р. (станом на 07.03.2017р.) відповідальність за діяння, які становлять собою статеві зносини 3 малолітньою особою, передбачається у ст.ст. 181-183 глави 2 «Про сексуальні зловживання» ${ }^{17}$. Статеві злочини у КК Іспанії об’єднані в окремий розділ VIII Особливої частини «Злочини проти статевої свободи» та складаються iз п'яти розділів: 1) «Про сексуальну агресію» (розділ 1); 2) «Про сексуальні зловживання» (розділ 2); 3) «Переслідування сексуального характеру» (розділ 3); 4) «Злочини, пов’язані з заняттям проституцією» (розділ 4); 5) «Загальні положення до попередніх глав» (розділ 5). При цьому не застосовуються терміни «розпусні дії» чи «статеві зносини 3 малолітнім». У КК застосовуються термінологічні звороти «сексуальне зловживання» $\mathrm{i}$ «сексуальне зловживання, що полягає у фізичному статевому акті шляхом введення предмета або в ротовому чи анальному проникненні». Перше діяння охоплює розпусні дії без статевих зносин (близька до ст. 156 КК України), а друге - статеві зносини з малолітньою особою (близька до ст. 155 КК України). До того ж КК Іспанії передбачає кілька складів злочинів, що полягають у ненасильницьких статевих зносинах iз неналежним партнером: a) сексуальне зловживання, що полягає у фізичному статевому акті шляхом введення предмета або в ротовому чи анальному проникненні, вчинених без згоди потерпілого щодо особи, яка не досягла 12 років, карається тюремним ув'язненням на строк від чотирьох до десяти років (абз. 1 ст. 182 КК Іспанії). За змістом термінів, застосовуваних у цьому розділі КК, відсутність згоди потерпілого необхідно розцінювати не як явне небажання потерпілого, яке суб'єкт злочину долає шляхом сексуальної агресії (тобто насильства чи залякування, характерних для згвалтування), а як відсутність чітко вираженої згоди чи неповне розуміння фактичної сторони того, що відбувається, певна байдужість тощо. Інакше кримінальна відповідальність настане як за сексуальну агресію; б) ті самі дії, вчинені за згодою потерпілого, але 3 використанням винуватим своєї явної переваги, караються на строк від одного року до шести років (абз. 1 ст. 182 КК Іспаніï). Кваліфікуючими ознаками діянь, передбачених ст. 182 КК Іспанії, позначені такі обставини: якщо злочин відбувається з використанням своїх родинних зв'язків, висхідних або спадних, із родичем чи братом (сестрою) - рідними чи за усиновленням; якщо жертва $\epsilon$ особливо

\footnotetext{
Уголовный

кодекс

Испании. URL:

http://law.edu.ru/norm/norm.asp?normID= 1247923\&subID=100111282,100111284,100111479,100111540,100111547\#text
} 
уразливою внаслідок свого віку, хвороби чи стану (у зазначених обставинах міри покарання, передбачені в попередніх абзацах, призначаються ближче до верхньої межі санкції) (абз. 2 ст. 182 КК Іспанії); якщо сексуальне зловживання, що полягає у фізичному статевому акті шляхом введення предмета або в ротовому чи анальному проникненні, відбувається 3 використанням обману щодо особи старшої 12, але молодшої 16 років, то воно карається тюремним ув'язненням на строк від шести місяців до трьох років (абз. 2 ст. 183 КК Іспанії). Таким чином, КК Іспанії диференціює кримінальну відповідальність за статеві зносини 3 особою, яка не досягла статевої зрілості, за двома критеріями: 1) за віком: а) щодо осіб до дванадцяти років; б) щодо осіб від 12 до 16 років; 2) за способом: а) без згоди потерпілого; б) за згодою потерпілого, але 3 використанням винуватим своєї явної переваги; в) 3 використанням обману.

\section{2. Протидія розбещенню особи, яка не досягла певного віку}

Вибіркове порівняльно-правове дослідження кримінальної відповідальності за розбещення неповнолітніх у деяких країнах СНД (Білорусь, Казахстан та Молдова) засвідчує неоднаковість як викладення основного складу розбещення неповнолітніх, так і кваліфікуючих ознак цього злочину та караності злочинних дій. Своєрідним шляхом пішов білоруський законодавець, який виокремив «застосування насильства або загрозою його застосування» у кваліфікуючу обставину. Утім, на наш погляд, варто було конкретизувати характер такого насилля у межах небезпечності для життя та здоров'я потерпілої особи. Як суттєвий недолік також варто вказати на відсутність у відповідних нормах КК Білорусі та Молдови згадки про спеціальний суб'єкт злочину, а саме: батьків, педагогів, вихователів або інших осіб, на яких покладені обов'язки 3 виховання неповнолітніх осіб. Так, Кримінальний кодекс РБ встановлює кримінальну відповідальність за розбещення неповнолітніх у ст. 169 КК «Розпусні дії» ${ }^{18}$. В ч. 1 цієї норми закріплено: «Розпусні дії, вчинені особою, що досягла вісімнадцятирічного віку, щодо особи, яка завідомо не досягла шістнадцятирічного віку, за відсутності ознак злочинів, передбачених статтями 166, 167, 168 цього Кодексу, караються арештом до шести місяців або позбавленням свободи на строк від одного року до трьох років». В ч. 2 ст. 169 КК РБ передбачаються ті ж самі дії, вчинені із застосуванням насилля або загрозою його застосування, що караються позбавленням свободи на строк від трьох до шести років.

\footnotetext{
18 Уголовный кодекс Республики Беларусь от 17.07.2018 г. Официальный сайт Верховного Совета Республики Беларусь. URL: http://www.sovrep.gov.by/ru/
} 
Кримінальний кодекс Республіки Казахстан не передбачає окремого розділу щодо статевих злочинів, а розміщує відповідні норми у Главі I Особливої частини КК «Кримінальні правопорушення проти особи». В ст. 124 КК РК встановлюється кримінальна відповідальність на розбещення малолітніх. В ч. 1 цієї статті передбачається відповідальність за вчинення розпусних дій без застосування насильства щодо свідомо малолітньої (малолітнього), що карається позбавленням волі на строк від п'яти до десяти років із позбавленням права обіймати певні посади чи займатися певною діяльністю на строк від семи до десяти років. Те саме діяння, вчинене щодо малолітньої (малолітнього) батьком, педагогом або іншою особою, на яку законом Республіки Казахстан покладено обов'язки 3 iï (його) виховання, карається позбавленням волі на строк від семи до дванадцяти років із довічним позбавленням права обіймати певні посади або займатися певною діяльністю (ч. 2 ст. 124). Діяння, передбачені ч. 1 або ч. 2 цієї статті, вчинені неодноразово, караються позбавленням волі на строк від десяти до п'ятнадцяти років із довічним позбавленням права обіймати певні посади або займатися певною діяльністю ${ }^{19}$.

Дещо по-іншому вирішує питання відповідальності за розпусні дії Кримінальний кодекс Республіки Молдова ${ }^{20}$. Ст. 175 КК РМ передбачає відповідальність за розпусні дії, вчинені щодо особи, яка завідомо не досягла 16 років, що полягають в ексгібіції, непристойних дотиках, бесідах непристойного або цинічного змісту про сексуальні стосунки, схилянні до участі або присутності на порнографічних виставах, надання матеріалів порнографічного змісту, а також в інших діях сексуального характеру, караються позбавленням волі на строк від 3 до 7 років.

3-поміж кримінальних законів країн $Є С$ прикладами різних напрямів розвитку кримінальної відповідальності за розпусні дії нами взяті КК ФРН, Іспанії та прибалтійських республік. Кримінальний кодекс ФРН статеві злочини передбачив у Розділі ХІІІ Особливої частини «Злочинні діяння проти статевого самовизначення». Він диференціює кримінальну відповідальність у залежності від віку потерпілої особи. На противагу КК інших держав, де відповідальність за вказані дії передбачається, як правило, в одній статті, в КК ФРН передбачено низку статей, що охоплюють відповідальність за вчинення ненасильницьких статевих зловживань, а саме: 1) сексуальні дії щодо опікуваних осіб (§ 174 КК); 2) сексуальні дії щодо дітей (§ 176 КК); 3) тяжкі сексуальні дії щодо дітей

\footnotetext{
19 Уголовный кодекс Республики Казахстан от 03.07.2014 г. № 226-V 3 июля 2014 г. № 226-V (с изменениями и дополнениями по состоянию на 21.01.2019 г.) URL: https://online.zakon.kz/Document/?doc_id=31575252\#pos=5;-245

${ }^{20}$ Уголовный кодекс республики Молдова. от 18.04.2002 г. Официильный сайт Верховного Совета Республики Молдова. URL: http://lex.justice.md/ru/331268/
} 
(§ 176а КК); 4) сексуальні дії щодо дитини, які спричинили іiі смерть (§ 176b КК); 5) пособництво сексуальним діям малолітніх (§ $180 \mathrm{KK})$; 6) сексуальні дії щодо неповнолітніх (п. 1 абз. $2 \S 182$ КК) ${ }^{21}$. Таке розмаїття норм є особливістю німецької законодавчої техніки, коли кваліфікуючі ознаки або форми співучасті виокремлюються в самостійні приписи кримінального закону, наприклад, сексуальні дії щодо дитини, які спричинили іiі смерть, чи пособництво сексуальним діям малолітніх. Безпосередньо як розбещення неповнолітніх можуть розглядатися три норми зазначеного розділу. По-перше, це $\S 174$ «Сексуальні зловживання щодо опікуваних осіб»: хто вчинить сексуальні дії щодо: 1) особи, яка не досягла шістнадцятирічного віку та ввірена йому для виховання, освіти або догляду; 2) особи, яка не досягла вісімнадцятирічного віку, та ввірена йому для виховання, освіти або догляду або знаходиться у підлеглому стані в рамках службових або трудових відносин, коли зловживання щодо цієї залежності особи зумовлені виховними, опікунськими, службовими або трудовими відносинами; 3) своєї кровної або прийомної дитини, яка ще не досягла вісімнадцятирічного віку або допускає вчинення такого діяння до себе з боку опукуваної особи, - карається позбавленням свободи на строк до п'яти років або грошовим штрафом (абз. 1 ст. 174 КК). Хто вчиняє ті самі дії, передбачені абз. 1, № 1-3: 1) вчиняє сексуальні дії у присутності опікуваної особи або 2) схиляє опікувану особу до вчинення сексуальних дій у його присутності, щоб сексуально збудитися самому або збудити опікувану особу, той карається позбавленням свободи на строк до трьох років, грошовим штрафом. У випадках, передбачених в абз. 1, № 1 або абз. 2 у зв'язку з абз. 1, № 1, суд згідно 3 цим приписом може відмовитися від покарання, якщо 3 урахуванням поведінки опікуваної особи неправомірність діяння $є$ незначною. По-друге, відповідальність за сексуальні зловживання щодо дітей передбачається $\S 176$ КК. У цій нормі передбачається, що той, хто вчиняє сексуальні дії щодо особи, яка не досягла чотирнадцятирічного віку (дитини) або дозволяє вчинювати такі дії йому щодо себе, карається позбавленням свободи на строк від шести місяців до десяти років, а в менш тяжких випадках покаранням $\epsilon$ позбавлення свободи на строк до п’яти років або грошовий штраф (№ 1). Такому ж покаранню підлягає той, хто схиляє дитину до вчинення сексуальних дій щодо третьої особи або дозволяє третій особі вчинювати такі дії щодо себе (№ 2). Позбавленням свободи на строк до п’яти років або грошовим штрафом карається той, хто: 1) вчиняє сексуальні дії у

\footnotetext{
${ }^{21}$ Уголовный кодекс Федеративной Республики Германии : в редакции от 13 ноября 1998 г. (обновлено: 24.01.2007 $\quad$ г.). URL: http://law.edu.ru/norm/norm.asp?normID=1242733\&subID= 100102942,100102944,100103620\#text.
} 
присутності дитини; 2) схиляє дитину до вчинення сексуальних дій із ним; 3) впливає на дитину, демонструючи їй порнографічні малюнки, зображення, даючи прослуховувати магнітофонні записи порнографічного характеру або проводить непристойні бесіди. По-трете, у $§ 182$ передбачаються такі різновиди сексуальних зловживань щодо неповнолітніх. Особа, що досягла вісімнадцятирічного віку, яка неправомірно використовує особу, яка не досягла шістнадцятирічного віку, такими діями: вчинює сексуальні дії щодо такої особи або допускає вчинення таких дій із його боку, використовуючи залежне положення або винагороду (№ 1) або використовуючи залежне положення, схиляє його до сексуальних дій щодо третьої особи або дозволяє третій особі вчинювати такі дії щодо себе (№ 2), - карається позбавленням свободи на строк до п'яти років або грошовим штрафом. Особа, що досягла 21-річного віку, яка неправомірно використовує особу, яка не досягла 16-річного віку, у вчиненні сексуальних дій або допущенні таких дій з боку такої особи щодо себе (№ 1), або схилянні його до сексуальних дій із третьою особою або допускає такі дії з його сторони та використовує при цьому відсутність у потерпілого спроможності до сексуального самовираження, - карається позбавленням свободи на строк до трьох років або грошовим штрафом.

КК Іспанії поділяє статеві злочини на сексуальну агресію та сексуальне зловживання. Згідно зі ст. 181 КК той, хто без застосування насилля чи залякування, не отримавши згоди, вчиняє дії, що посягають на статеву свободу іншої особи, карається як винний у сексуальному зловживанні штрафом у розмірі від дванадцяти до двадцяти щомісячних заробітних плат ${ }^{22}$. У всіх випадках визнаються сексуальними зловживаннями дії, вчинені без згоди потерпілої особи: 1) проти осіб, які не досягли дванадцятирічного віку; 2) проти осіб, позбавлених розуму або зловживаючи їхніми душевними розладами, - караються тюремним ув'язненням на строк від шести місяців до двох років. У ст.ст. 185, 186 КК Іспанії передбачається кримінальна відповідальність за такі різновиди розпусних дій, як «непристойні ексгібіціоністські дії перед особами, які не досягли шістнадцятирічного віку» та «розповсюдження, продаж та показ порнографічних матеріалів особам, які не досягли шістнадцятирічного віку».

Закони прибалтійських країн передбачають розбещення як статевий злочин проти моральності або статевої недоторканості. В ст. 162 КК Латвійської Республіки ${ }^{23}$ під розбещенням розуміється вчинення повнолітньою особою розпусних дій щодо неповнолітнього проти його

\footnotetext{
22 Уголовный кодекс Испании. URL: http://law.edu.ru/norm/norm.asp?normID=1247923\&subID= 100111282,100111284,100111479,100111540,100111547\#text

${ }_{23}$ Уголовный закон Латвийской Республики 17.07.1998 г. Сейм Латвийской Республики. URL: http://www.pravo.lv/likumi/07_uz.html.
} 
волі, що карається позбавленням свободи на строк до трьох років або арештом (ч. 1). Вчинення розпусних дій щодо малолітнього карається позбавленням свободи на строк до шести років (ч. 2). В ст. 153 КК Литовської Республіки передбачається відповідальність за розпусні дії щодо малолітньої особи - штраф або обмеження свободи, або арешт, або позбавлення свободи на строк до двох років ${ }^{24}$. Пенітенціарний кодекс Естонії в ст. 147-1 передбачає купівлю сексуальних послуг у неповнолітнього у такому вигляді: 1) вступ до статевих зносин або скоєння іншої дії сексуального характеру 3 особою, яка не досягла вісімнадцятирічного віку, за грошову винагороду чи будь-яке інше благо караються тюремним ув'язненням на термін до трьох років; 2) зазначене в ч. 1 цієї статті діяння, вчинене щодо особи, яка не досягла чотирнадцятирічного віку, карається тюремним ув'язненням на термін до п’яти років; 3) зазначені в ч.ч. 1, 2 цієї статті діяння, вчинені особою, яка раніше вчинила злочин, передбачений цим розділом, караються тюремним ув'язненням на термін від двох до восьми років; 4) зазначені в ч.ч. 1 і 2 цієї статті діяння, вчинені юридичною особою, караються грошовим стягненням; 5) за вчинення злочину, зазначеного в ч.ч. 2 і 3 цієї статті, суд може застосувати розширену конфіскацію майна, здобутого в результаті злочину, відповідно до положень ст. 832 цього Кодексу ${ }^{25}$.

\section{ВИСНОВКИ}

Проведене компаративне дослідження КК України, деяких зарубіжних країн СНД та СС засвідчує, що кримінальна відповідальність за статеві злочини проти дітей та підлітків встановлена в усіх країнах. Серед статевих злочинів проти неповнолітніх вони займають відповідне місце, здебільшого як середньої тяжкості суспільно-небезпечне посягання на статеве самовизначення неповнолітніх. Кримінальна відповідальність передбачена у разі вчинення сексуальних дій повнолітніми особами, тому саме на них покладений соціальний контроль за усталений уклад статевих відносин у суспільстві. У більшості КК вона диференціюється у залежності від віку потерпілої особи, посилюючись у зв'язку з недосягненням дванадцятирічного або чотирнадцятирічного віку. Пеналізація цих злочинів варіюється від кримінального проступку до тяжкого злочину. Як кваліфікуючі обставини, як правило, вказуються ознаки спеціального суб'єкта злочину - батьки, вихователі, інші особи, які за законом здійснюють догляд за дітьми.

\footnotetext{
24 Уголовный закон Литовской Республики 26.07.2000 г. URL: http://www.law.edu.ru/norm/ norm.asp?normID=1243877\&subID=100107735,100107738,100107759,100107839\#text

${ }^{25}$ Пенитенциарный кодекс Эстонии 06.06.2001 г. URL: https://v1.juristaitab.ee/sites/www.juristaitab.ee/ files/elfinder/ru-seadused/
} 


\section{АНОТАЦІЯ}

Метою дослідження $є$ встановлення сучасних тенденцій розвитку України та деяких зарубіжних країн щодо протидії ненасильницьким статевим злочинам проти неповнолітніх осіб. У науковому нарисі 3 позицій компаративістики розкривається складність і суперечливість сучасного стану та перспектив розвитку кримінально-правової боротьби 3 сексуальною експлуатацією дітей та підлітків в Україні та інших державах. Встановлено актуальні тенденції кримінальної відповідальності, що полягають в диференційованому підході до віку як потерпілої, так й винної особи. Простежується зв'язок посилення відповідальності у разі вчинення цих дій близькими родичами або членами сім'ї особою, на яку покладено обов'язки щодо виховання потерпілого або піклування про нього. Санкції відповідних норм передбачають доволі суворі кримінальні покарання за вчинення сексуальних злочинів проти неповнолітніх осіб. Всупереч цьому, законодавець деяких країн передбачив випадки звільнення від кримінальної відповідальності та покарання у разі незначної різниці у віці потерпілої та винної особи. Перспективними вважаємо напрями більш чіткого розмежування за об'єктивними ознаками ненасильницьких статевих злочинів проти неповнолітніх осіб.

\section{ЛІТЕРАТУРА}

1. Про внесення змін до Кримінального кодексу України щодо захисту дітей від сексуальних зловживань та сексуальної експлуатації : Закон України від 14 березня 2018 р. Відомості Верховної Ради. 2018. № 17. Ст. 150.

2. Уголовный кодекс Грузии от 22 июля 1999 г. Законодательный вестник Грузии. URL: https://matsne.gov.ge/ru/document/view/ 16426? publication $=205$.

3. Уголовный кодекс Республики Беларусь от 17 июля 2018 г. Офиииальный сайт Верховного Совета Республики Беларусь. URL: http://www.sovrep.gov.by/ru/.

4. Уголовный кодекс республики Молдова. от 18 апреля 2002 г. Офиииальный сайт Верховного Совета Республики Молдова. URL: http://lex.justice.md/ru/331268/.

5. Уголовный кодекс Латвийской Республики 17 июня 1998 г. Сейм Латвийской Республики. URL: http://www.pravo.lv/likumi/07_uz.html.

6. Уголовный закон Литовской Республики 26 июня 2000 г. URL: http://www.law.edu.ru/norm/norm.asp?normID=1243877\&subID=100107735,1 00107738,100107759,100107839\#text. 
7. Пенитенциарный кодекс Эстонии 06 июня 2001 г. URL: https://v1.juristaitab.ee/sites/www.juristaitab.ee/files/elfinder/ru-seadused/.

8. Уголовный кодекс Азербайджанской Республики от 30 декабря 1999 г. URL: http://law.edu.ru/norm/norm.asp?normID=1242908\&subID= $100104131,100104133100104144,100104987,100105115$.

9. Уголовный кодекс Республики Армения от 29 апреля 2003 p. URL: http://www.parliament.am/legislation.php?sel=show\&ID=1349\&lang=rus\#18

10. Уголовный кодекс Республики Узбекистан від 24 сентября 1994 г. Законы Республики Узбекистан. URL: http://lex.uz/docs/111457\#158462.

11. Уголовный кодекс Республики Польша от 1 января 1997 г. URL: http://law.edu.ru/norm/norm.asp?normID=1246817\&subID=100110056,100110 058,100110087,100110285\#text.

12. Уголовный кодекс Болгарии. Опубликовано 27 ноября 2011 г. URL: http://ugolovnykodeks.ru/2011/11/ugolovnyj-kodeks-bolgarii/.

13. Уголовный кодекс Австрии. Москва : Юридическая литература, 2004. 352 c. URL: https://www.livelib.ru/book/1001353291/about-ugolovnyjkodeks-avstrii/.

14. Уголовный кодекс Испании. URL: http://law.edu.ru/norm/norm.asp? normID=1247923\&subID=100111282,100111284,100111479,100111540,1001 11547\#text.

15. Уголовный кодекс Федеративной Республики Германии от 13 ноября 1998 г. URL: http://law.edu.ru/norm/norm.asp? normID=1242733\&subID=100102942,100102944,100103620\#text.

\section{Information about authors:} Khryapynskyi P. V.,

Doctor of Law, Professor,

Honored Worker of Science and Technology of Ukraine, Professor of the Department of Criminal Law and Criminology of the National Technical University "Dniprovska Polytechnic" pr. 19 Dmitryi Yavornytskyi, Dnipro, Ukraine

Svitlychnyi O. O.,

Candidate of Sciences (Law), Associate Professor, Associate Professor of the Department of Criminal Law and Criminology of the National Technical University "Dniprovska Polytechnic" pr. 19 Dmitryi Yavornytskyi, Dnipro, Ukraine 